\title{
A colorimetric-based bioreporter for rapid genotoxicity monitoring using Escherichia coli
}

\author{
Naruemon Chumjai ${ }^{\mathrm{a}, \mathrm{b}}$, Alisa S. Vangnai ${ }^{\mathrm{b}, \mathrm{c}, *}$ \\ a International Program in Hazardous Substance and Environmental Management, Graduate School, \\ Chulalongkorn University, Bangkok 10330 Thailand \\ b Center of Excellence on Hazardous Substance Management (HSM), Chulalongkorn University, Bangkok \\ 10330 Thailand \\ c Biocatalyst and Environmental Biotechnology Research Unit, Department of Biochemistry, Faculty of \\ Science, Chulalongkorn University, Bangkok 10330 Thailand
}

*Corresponding author, e-mail: alisa.v@chula.ac.th

Received 9 Mar 2020

Accepted 21 Apr 2020

\begin{abstract}
Environmental contamination of genotoxic agents has been a concern due to their ability to cause cellular DNA damages or cancer. In this work, the bioreporter $\mathrm{P}_{\text {rec } A} l a c Z$ was constructed based on Escherichia coli by fusing a promoter of a DNA damage response gene (recA) to a $\beta$-galactosidase reporter gene (lacZ), which is called E. coli-recA bioreporter (EREC). For a reliable measurement, a level of the genotoxicity was normalized by bacterial cell respiration. Well-known genotoxic agents including sodium azide, 4-nitroquinoline 1-oxide and benzene were individually exposed to EREC in comparison with Ames test and commercial SOS-Chromotest ${ }^{\mathrm{TM}}$. The EREC was able to detect the genotoxic levels of all tested genotoxic agents, i.e. at 5, 31 and $1563 \mathrm{mg} / \mathrm{L}$ for sodium azide, 4-nitroquinoline 1-oxide and benzene, respectively, while the other two tests were unable to detect the genotoxicity of benzene even at lethal concentrations. A practical platform of genotoxic level detection was further developed based on EREC as freeze-dried cells on a microtiter plate. The freeze-dried EREC, kept at $-20^{\circ} \mathrm{C}$ for three months, was able to maintain cell survival of more than $97 \%$ and genotoxic sensitivity comparable to that of the freshly prepared cells. The freeze-dried EREC was also able to detect the genotoxicity of representative environmental-polluted pesticides including Chlorpyrifos, Profenofos and Cypermethrin at 25, 100 and $100 \mathrm{mg} / \mathrm{L}$, respectively, and at the maximum residue limits permitted in agriculture commodity of pesticide mixtures thereof. In conclusion, the EREC can be further applied as a high-throughput genotoxicity screening of environmental pollutants either as individuals or combinations thereof.
\end{abstract}

KEYWORDS: bioreporter, freeze-dried bacteria, Escherichia coli, genotoxicity, pesticide

\section{INTRODUCTION}

Large quantities of hazardous wastes generated from industrial activities containing genotoxic agents pose a threat to humans due to the effects of cellular DNA damage, leading to mutation or cancer [1]. Bioassay is an alternative method to detect environmental pollutants using living prokaryotic or eukaryotic organisms. Among all of the organisms, the bacterial-based bioassay is receiving increasing attention due to its ability to be geneticallyengineered for specific sensing, high sensitivity and selectivity, low cost, short time for measurement and faster growth rate than animals or plants [2].

Nowadays, one of the most widely recognized bacteria-based bioassays is the Salmonella mutagenicity assay or Ames test. For this test, Salmonella typhimurium strains TA98 and TA100, containing the $r f a$ and $u v r B$ mutation and R-factor plasmid
pKM101, all of which could enhance the sensitivity of detection are widely used. S. typhimurium strains carry mutations in genes involved in histidine synthesis $\left(\right.$ his $^{-}$), thus these strains cannot produce histidine which is required for bacterial growth. When tested substance causes mutation or reverses mutation at the histidine point $\left(\mathrm{his}^{+}\right)$, the bacteria cell can grow on histidine-free medium $[3,4]$. However, the disadvantage of this assay is the timeconsuming process, requiring two days for incubation of agar plates under selective conditions. Moreover, a skilled operator and labor intensiveness based on plate incorporation test are required [5]. Another famous approach for genotoxicity detection is a recombinant bacterial bioreporter based on the activation of the bacterial SOS response involved in the DNA damage system. Several colorimetric assays for screening the genotoxicity of environmen- 
tal pollutants have been developed; for example, the Rec-lac test [6], umu test [7] and the SOSChromotest [8]. In all of these tests, the SOS system is fused to $\beta$-galactosidase; lacZ is used as a reporter gene, and the chromogenic $\beta$-galactosidase activity is measured to determine genotoxicity. For the commercial SOS-Chromotest ${ }^{\mathrm{TM}}$ using Escherichia coli PQ37, the structural gene for $\beta$-galactosidase is placed under the control of the sfi promoter involved in cell division. The $r f a$ and $u v r A$ genes of this strain are modified to increase the sensitivity to genotoxicants [9]. Nevertheless, substantial time is required due to the overnight reconstitution of lyophilized bacteria and hours of the genotoxic test process. Additionally, the cost of SOS-Chromotest ${ }^{\mathrm{TM}}$ is considerably high at 300-600 US dollars per kit (Environmental Bio-Detection Products Inc).

The aim of this study is to develop a color-based bacterial bioreporter for genotoxicity detection, of which the efficacy is validated with Ames test for mutagenicity and commercial SOS-Chromotest ${ }^{\mathrm{TM}}$ for genotoxicity detection. In this work, the lacZ-based $E$. coli bioreporter under the control of recA promoter was constructed for the qualitative detection of the genotoxic compounds using visible observation of color gradient and the quantitative analysis using spectrophotometry. E. coli was selected as a host since it is a model strain widely used for genetic modification. The recA gene was selected based on its role in homologous recombination, induction of the SOS response and the mutagenic repair of DNA. In addition, recA promoter offers the most dramatic and sensitive response compared with uvrA and alkA [10]. The dose response of $\beta$ galactosidase production was measured and used as an indicator of genotoxicity. Bacterial metabolic activity based on bacterial respiration was used to ensure the survivability of the cells from high chemical concentrations used, which might lead to an underestimation of $\beta$-galactosidase induction. For long-term preservation and transport for on-site uses, the bioreporter was developed as freeze-dried cells. By studying the effects of model pesticides as individuals and combinations of pesticide mixtures, the pesticide used in this study included carbendazim that is classified as unlikely to be hazard while carbaryl, cypermethrin, chlorpyrifos and profenofos are classified as a class II, moderately hazardous pesticide according to the World Health Organization (WHO). Chlorpyrifos, cypermethrin, carbendazim showed genotoxic potential in human tissues or cells and can induce chromosome aberrations $[11,12]$. Profenofos has been reported to be genotoxic on freshwater snails [13]. This bioreporter is intended to be a rapid, simple and low-cost tool for genotoxicity detection for large number of test samples.

\section{MATERIALS AND METHODS}

\section{Chemicals and media}

All chemicals used were analytical-grade purchased from Sigma-Aldrich (USA) or Merck (Germany). Five commercial-grade pesticides including carbendazim (50\% WP), profenofos (50\% w/v), cypermethrin (35\% w/v), carbaryl (85\% WP) and chlorpyrifos $(40 \% \mathrm{w} / \mathrm{v})$ were purchased from a local distributor (Syngenta Crop Protection Co., Thailand). The stock solution was dissolved in ethanol, then diluted to the desired concentrations using $10 \%$ (v/v) DMSO.

The cultivation media was Luria-Bertani (LB) medium ( $\mathrm{pH}$ 7.0). The resuspended or rehydrated medium was M9G medium (M9 minimal medium (per liter): $\mathrm{Na}_{2} \mathrm{HPO}_{4} \cdot 12 \mathrm{H}_{2} \mathrm{O}, 15.05 \mathrm{~g} ; \mathrm{KH}_{2} \mathrm{PO}_{4}$, $3 \mathrm{~g} ; \mathrm{NaCl}, 0.5 \mathrm{~g} ; \mathrm{NH}_{4} \mathrm{Cl}, 1 \mathrm{~g} ; \mathrm{MgSO}_{4}, 1 \mathrm{mM} ; \mathrm{CaCl}_{2}$, $0.1 \mathrm{mM}$; and supplemented with $0.2 \%$ glucose). Agar was added for solid medium at $15 \mathrm{~g} / \mathrm{L}$.

\section{Construction of EREC bioreporter}

E. coli DH5 $\alpha\left(F^{-}, \phi 80 d l a c Z \Delta M 15, \quad \Delta\right.$ (lacZYA$\operatorname{argF)U169,}$ deoR, recA1, endA1, $h s d R 17\left(r_{k}^{+}, m_{k}^{+}\right)$, phoA, supE44, $\lambda^{-}$, thi-1, gyrA96, relA1) was used as a host strain for bioreporter construction in this study. E. coli K-12 MG1655 is a laboratory strain, and $r e c A$ promoter from this strain was selected as a model. The recA promoter was amplified by polymerase chain reaction (PCR). This promoter segment was integrated into the HindIII and XbaI sites of promoterless pUClacZ plasmid adjacent to the lacZ gene to develop $\mathrm{P}_{\text {recA }}$ lacZ (Fig. S1). E. coli DH5 $\alpha$ harboring this recombinant plasmid is called EREC bioreporter and used for genotoxicity detection.

\section{Characterization of EREC bioreporter with toxic agents}

E. coli EREC cells were grown aerobically in LB medium with $100 \mu \mathrm{g} / \mathrm{mL}$ ampicillin at $37^{\circ} \mathrm{C}$ under $150 \mathrm{rpm}$ of shaking until the exponential phase $\left(\mathrm{OD}_{600}=0.3-0.4\right)$. An antibiotic, ampicillin, was added to maintain the recombinant vector during cell cultivation. The cultures were then centrifuged at $4500 \times \mathrm{g}$ and $4{ }^{\circ} \mathrm{C}$ for $15 \mathrm{~min}$ and washed twice with $0.85 \% \mathrm{NaCl}$ before resuspended in the same volume of M9G medium. One hundred $\mu \mathrm{L}$ of the suspended cells (the initial concentration of 
bacterial cell was $\left.1 \times 10^{8} \mathrm{CFU} / \mathrm{mL}\right)$ was aliquoted into a microtiter plate (Nunc ${ }^{\mathrm{TM}}$ Microwell ${ }^{\mathrm{TM}}$ ) following an exposure to $100 \mu \mathrm{L}$ of the tested chemical at various concentrations: sodium azide (positive control of Ames test), 4-nitroquinoline 1oxide (positive control of SOS-Chromotest ${ }^{\mathrm{TM}}$ ) and benzene (known as a human carcinogen). After incubating at $37^{\circ} \mathrm{C}$ for $60 \mathrm{~min}$, the substrate $\mathrm{X}$ gal $(1 \mathrm{mg} / \mathrm{mL})$ was added, followed by $30 \mathrm{~min}$ of incubation for $\beta$-galactosidase production (BG), resulting in blue color. For bacterial respiration, $10 \mu \mathrm{L}$ of $0.9 \mathrm{M}$ ferricyanide was added to $100 \mu \mathrm{L}$ of the cell suspension and incubated at $37^{\circ} \mathrm{C}$ for 60 min, after that $10 \mu \mathrm{L}$ of $0.025 \mathrm{M} \mathrm{FeCl}_{3}(\mathrm{pH} 0.6)$ was added and mixed to form colorimetric product Prussian Blue (PB), resulting in green color [14]. The BG and the PB concentrations were measured by UV-visible plate reader (Multiscan GO, Thermo scientific) at $660 \mathrm{~nm}$. BG is determined from $A b_{\text {induce }} / A b_{\text {non-induce }}$ while $\mathrm{PB}$ is determined from $A b_{\text {non-induce }} / \mathrm{Ab}_{\text {induce}}$, in which $A b_{\text {non-induce }}$ is the absorption intensity at $\mathrm{OD}_{660}$ produced by the noninduced cells and $A b_{\text {induce }}$ is that of cells induced with toxic agents. The induction factor was modified from SOS-Chromotest ${ }^{\mathrm{TM}}$, which is defined as the $\mathrm{BG} / \mathrm{PB}$ ratio of the induced cells divided by the ratio of non-induce cells. If the induction factor $>2.0$, the tested compound is classified as genotoxic [15]. The principles of the genotoxicity detection by $\beta$-galactosidase production and the bacterial respiration by $\mathrm{PB}$ production of the bioreporter are described in Supplementary material (Fig. S2).

\section{Ames test and SOS-Chromotest ${ }^{\mathrm{TM}}$}

The Ames test was performed using bacteria Salmonella typhimurium strain TA100 to determine the mutagenic activity of the chemicals [4]. The mutagenicity is determined by the ratio between Induced revertant colonies (IR) and the Natural revertant colonies (NR), with the ratio $>2$ indicating the mutagenic potential.

For genotoxicity detection, the SOSChromotest $^{\mathrm{TM}} \quad$ (Environmental Bio-Detection Products Inc. (EBPI)) was performed according to the manufacturer's procedures using bacteria E. coli PQ37 (sfi:lacZ) $[8,15]$. $\quad \beta$-galactosidase (BG) and alkaline phosphatase (AP) activities were assayed. The SOS induction factor is defined as the $\mathrm{BG} / \mathrm{AP}$ ratio of the sample divided by the ratio of control (non-exposure cell). The test compound showing an SOS induction factor $>2.0$ is classified as genotoxic.

\section{Freeze-drying of EREC bioreporter}

Cells were resuspended in M9G medium with 10\% $(\mathrm{w} / \mathrm{v})$ dextrose as cryoprotectant. Initial cell concentration $\left(10^{8} \mathrm{CFU} / \mathrm{mL}\right)$ was determined using colony-forming unit (CFU) technique. The bacterial cultures were aliquoted into a microtiter plate (100 $\mu \mathrm{L}$ per well), then frozen at $-80^{\circ} \mathrm{C}$ overnight and lyophilized at $-51{ }^{\circ} \mathrm{C}$ with a vacuum of $0.2 \mathrm{mBar}$ pressure (Freeze Dryer, LABCONCO). After 5-6 h of freeze-drying, the lyophilized cells were sealed under vacuum in an aluminum foil bag and stored at different temperatures; room temperature (RT; $\left.25^{\circ} \mathrm{C}\right), 4^{\circ} \mathrm{C}, 0^{\circ} \mathrm{C}$ or $-20^{\circ} \mathrm{C}$ for 3 months until use. After rehydration with $100 \mu \mathrm{L}$ of M9G medium, the number of colonies forming units (CFU) for each sample was determined by serially diluting the sample and plating on LB agar. The plates were incubated for $24 \mathrm{~h}$ at $37^{\circ} \mathrm{C}$. Viabilities were determined as the survival colonies of freeze-dried storage at different temperatures compared to the number of colonies before storage. The activities were measured as bacterial respiration and genotoxicity induction factor when exposed to sodium azide at various concentrations.

\section{The freeze-dried EREC bioreporter tests with pesticides}

For the test, serial 2-fold dilutions of pesticides were prepared with $10 \%$ DMSO to the final concentrations ranging from 0.2 to $1000 \mathrm{mg} / \mathrm{kg}$. In addition, the mixtures of pesticides at the MRLs level of each pesticide were investigated.

\section{Statistical analysis}

Each treatment was performed in triplicate, and the results were presented as means with the standard deviation of the data presented as error bars. Experimental data were statistically analyzed using oneway ANOVA by Dunnett's multiple comparison test (GraphPad Prism version 5, GraphPad Software, La Jolla, California, USA) with $p<0.05$ considered statically significant.

\section{RESULTS AND DISCUSSION}

\section{Construction of EREC bioreporter}

E. coli $\mathrm{DH} 5 \alpha$ harboring plasmid $\mathrm{P}_{\text {recA }}$ lacZ was successfully constructed. The ferricyanide-based bacterial respiration yielded the orange color when bacteria cells were completely inactivated as determined by CFU technique. Bacterial cell death led to an underestimation of $\beta$-galactosidase induction since it yielded low intensity of blue color (Fig. S3). 
Accordingly, the orange color was used as a cutoff for further $\beta$-galactosidase-based genotoxicity determination, and the bacterial respiration of more than $20 \%$ is required to confirm a positive result. The genotoxic potential of a sample based on $\beta$ galactosidase production is also scaled by the survival of the cells, measured through the formation of $\mathrm{PB}$, allowing for the calculation of the genotoxicity induction factor.

\section{Response of EREC bioreporter to toxic agents}

Sodium azide is the standard mutagen [16] while 4nitroquinoline 1-oxide and benzene are reported as the human carcinogens [17]. The dose-dependent response of EREC to all toxic agents was observed (Fig. 1). Exposure to $5 \mathrm{mg} / \mathrm{L}$ of sodium azide, which is the minimum detectable genotoxic concentration, inhibited $50 \%$ of bacterial respiration (Fig. 1a). The EREC gave positive genotoxicity to sodium azide at 5 to $5000 \mathrm{mg} / \mathrm{L}$. The result agreed with the previous report that $5000 \mathrm{mg} / \mathrm{L}$ of sodium azide was genotoxic to E. coli WP100 (uvrA $\left.{ }^{-}, r e c^{-}\right)$[18]. In case of 4-nitroquinoline 1-oxide, the genotoxicity was detected when exposed to $31 \mathrm{mg} / \mathrm{L}$, resulting in 50\% inhibition of bacterial respiration (Fig. 1b). It should be noted that the positive genotoxicity limit of the bioreporter developed in this study was reasonable as it was still in the range reported in the other study, which varied from 10 to $10000 \mathrm{mg} / \mathrm{L}$ [19]. In addition, using different bacterial host cells and reporter systems, bioreporter offered varied genotoxicity detection levels $[8,20]$. Compared with the other chemicals, the genotoxicity of benzene was detected at much higher concentration, i.e. $781 \mathrm{mg} / \mathrm{L}$ in which the bacterial respiration was reduced to 20\% (Fig. 1c). Benzene has been reported to produce many types of genetic damages including chromosome aberrations and DNA double-strand breakage [21]. When cells are exposed to DNA damage, RecA protein is induced to attain much higher levels [22]. Jiang et al [23] reported that bioreporter DH5 $\alpha$ _lux (recA:luxCDABE), of which $r e c A$ promoter was cloned from the marine bacterium Vibrio natriegens and fused to a luminescent reporter gene, could monitor the genotoxicity of benzene at $0.08 \mathrm{mg} / \mathrm{L}$. The difference in detection limits may be due to the variations in the sources of recA gene, reporter gene and test conditions. It was found that the bioluminescent reporter gene showed 10- to 1000 -fold higher assay sensitivity compared to the fluorescent protein [24]; however, its instability at tropical temperature $\left(30-37^{\circ} \mathrm{C}\right)$ and the luminometer requirement become the limitations of the bioluminescent reporter gene. Therefore, the EREC in this study has offered high potential in applications for genotoxicity detection.

\section{Validation of EREC bioreporter to Ames test and} commercial SOS-Chromotest $^{\mathrm{TM}}$

Sodium azide is the positive control of Ames test using S. typhimurium strain TA100 [25]. The exposure to more than $0.78 \mathrm{mg} / \mathrm{L}$ of sodium azide induces mutagenic activity with the revertant frequency ratio of more than 2.0. A decreased revertant frequency was observed with the increasing concentration of sodium azide, indicating the dosedependent cytotoxicity effect on the strain. While 4-nitroquiloline 1-oxide was reported for its genotoxicity when tested with strain TA100 [14], this strain showed negative effect on benzene genotoxicity detection (Fig. S4) since the strain was killed by benzene due to the absence of the enzyme superoxide dismutase (SOD). In addition, oxidative stress due to the presence of benzene also induced DNA strand breaks, causing cytotoxic to strain. The more cytotoxic benzene offered in comparison to its mutagenic activity, the less its possibility to be detected by the Salmonella assay [26].

The commercial SOS-Chromotest ${ }^{\mathrm{TM}}$ is for genotoxic detection, based on DNA damage measured through the SOS-DNA repair system using engineered E. coli PQ37 (sfi:lacZ). 4-nitroquinoline 1oxide is the positive control of SOS-Chromotest ${ }^{\mathrm{Tm}}$, showing the positive genotoxic at concentration $\geqslant 0.06$ to $1 \mathrm{mg} / \mathrm{L}$ with the SOS-induction factor more than 2.0. However, SOS-Chromotest ${ }^{\mathrm{TM}}$ gave a negative result for sodium azide and benzene (Fig. S5). The negative effect on benzene of SOS-Chromotest ${ }^{\mathrm{TM}}$ was still ambiguous [27]. Flegrova et al [28] reported that sodium azide was also negative under SOS-Chromotest ${ }^{\mathrm{T}}{ }^{\mathrm{m}}$. However, the positive result with sodium azide was already obtained via the induction of a specific point mutation in the recA test and Vitotox test (SOS response promoter; recN fused with luxCDABE reporter gene).

The efficacy of constructed EREC was compared to the Ames test and SOS-Chromotest ${ }^{\mathrm{TM}}$, focusing on the mutagenicity/genotoxicity (Table 1). The result showed that the developed bioreporter could detect mutagenicity and genotoxicity of sodium azide and 4-nitroquinoline 1-oxide corresponding to the benchmark Ames test and commercial SOSChromotest $^{\mathrm{TM}}$, respectively. The higher sensitivity of the Ames test and SOS-Chromotest ${ }^{\mathrm{Tm}}$, compared to the developed bioreporter, is due to the fact that the Salmonella strain had the modifications to increase 
(a)

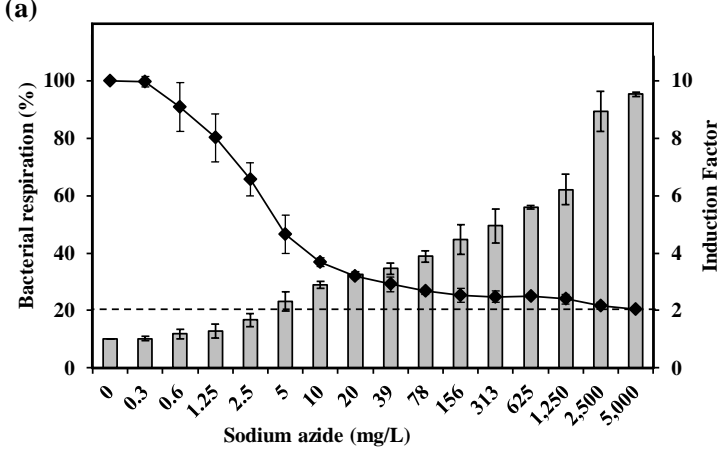

(b)

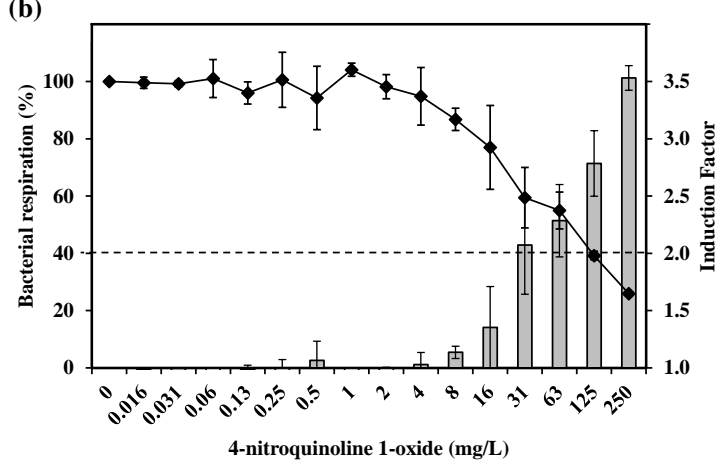

(c)

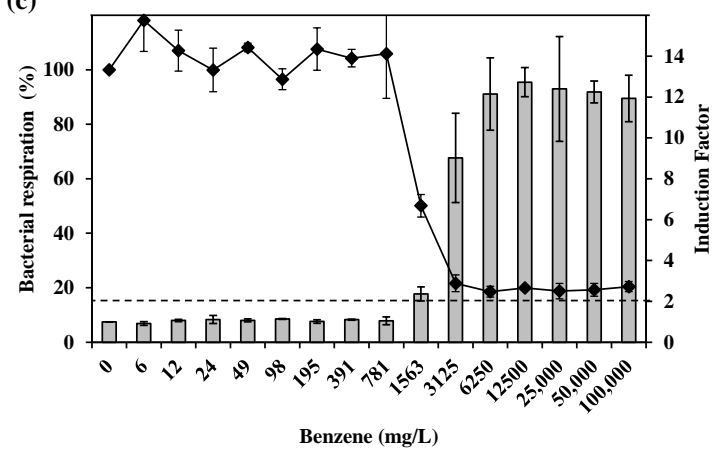

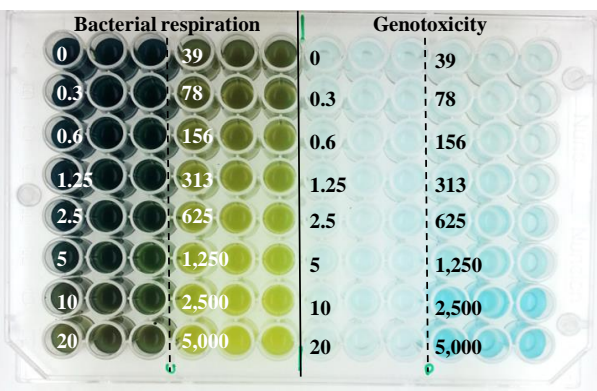
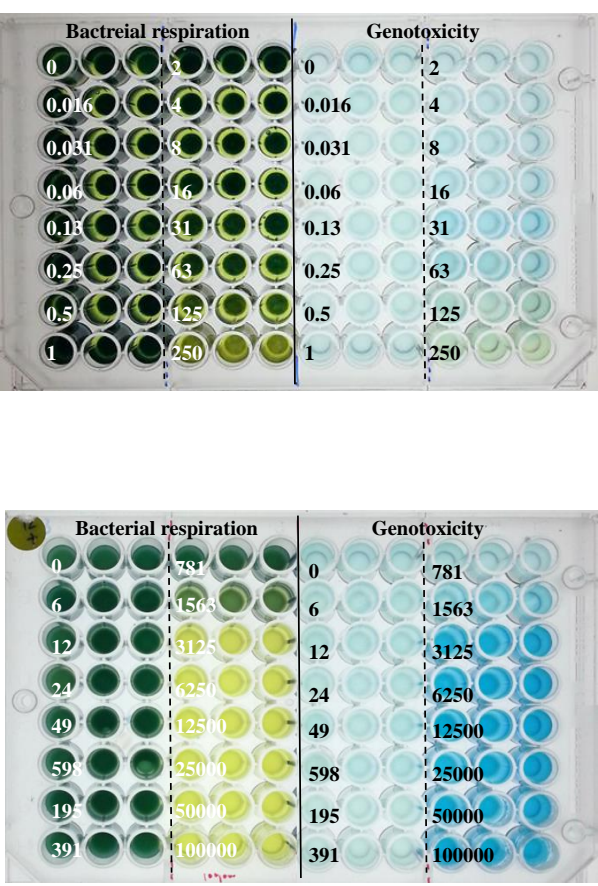

Fig. 1 Bacterial respiration (line) and genotoxicity induction factor (bar) of the EREC bioreporter when exposed to (a) sodium azide, (b) 4-nitroquinoline 1-oxide and (c) benzene at $37^{\circ} \mathrm{C}$ for $1 \mathrm{~h}$. The control was performed in $10 \%$ DMSO with no tested chemical. The first concentration above the dash line was reported as the minimum genotoxic concentration. Data are shown as the mean $\pm \mathrm{SD}$, derived from at least three independent repeats, and the error bars represent the errors of the mean.

sensitivity to mutagens. The SOS-Chromotest ${ }^{\mathrm{TM}}$ bacterial strain also has modifications to increase sensitivity to genotoxicity including the altered DNA repair system, the modified outer membrane to increase permeability and the modified SOS promoter [29]. While EREC and SOS-Chromotest ${ }^{\mathrm{TM}}$ used the same concept by fusing SOS response promoter to lacZ reporter gene, these two tests gave different results due to different $E$. coli strains and promoter function. The recA used in EREC is a multifunctional gene that is related to genetic recombination, regulating genes response to DNA damage and involved in highly mutagenic DNA repair while sfi used in strain PQ37 of SOS-Chromotest ${ }^{\mathrm{TM}}$ is involved in cell division inhibition.

From the results, the developed bioreporter has the potential to detect the mutagenicity and genotoxicity of various chemicals, some of which even 


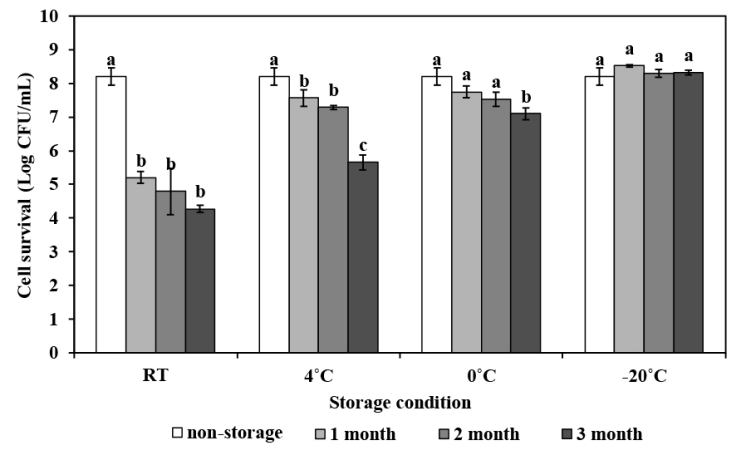

Fig. 2 Cell survival of freeze-dried bacteria stored at room temperature (RT, $25^{\circ} \mathrm{C}$ ), $4{ }^{\circ} \mathrm{C}, 0^{\circ} \mathrm{C}$ and $-20^{\circ} \mathrm{C}$ up to 3 months compared to a non-storage freeze-dried cell. Each value presents the means $\pm \mathrm{SD}$, derived from at least three independent repeats, and the error bars represent the errors of the mean. In the same storage temperature, according to Dunnett's multiple comparison test, significant differences at $p<0.05$ levels over control (non-storage) are indicated by different letters.

show false negative in the traditional Ames test and SOS-Chromotest ${ }^{\mathrm{Tm}}$. The developed bioreporter was a rapid test using $1.5 \mathrm{~h}$ assay time compared to that of the Ames test and SOS Chromotest ${ }^{\mathrm{TM}}$ using 3-5 days and $2-3.5 \mathrm{~h}$, respectively. In addition, the developed bioreporter cost is comparatively less than SOS-Chromotest ${ }^{\mathrm{TM}}$ because the imported commercial products may include tax, transportation fee, packaging fee, knowledge fee, etc.

\section{Freeze-dried EREC bioreporter}

The storage temperature was varied in order to achieve optimal preservation of the viability and activity of EREC up to 3 months. Bioreporter had been dried and stored in the presence of $10 \%(\mathrm{w} / \mathrm{v}) \mathrm{dex}-$ trose as a cryoprotectant since sugar has been shown to protect both membrane and protein intact bacteria during freeze-drying [30]. The result showed that room temperature $\left(\mathrm{RT}, 25^{\circ} \mathrm{C}\right.$ ) and $4^{\circ} \mathrm{C}$ were not the suitable temperature due to the decreasing cell viability during storage time (Fig. 2). While the storage at $0{ }^{\circ} \mathrm{C}$ showed no significant decrease in cell viability up to 2 months, the best maintenance of cell survival during prolonged storage was obtained when cells were stored at $-20^{\circ} \mathrm{C}$, of which cell viability remained more than $97 \%$ after 3 months. Similarly, the lyophilized E. coli strains for toxicity monitoring were stored up to several months at $-20^{\circ} \mathrm{C}[31]$.

The freeze-dried cells were rehydrated and
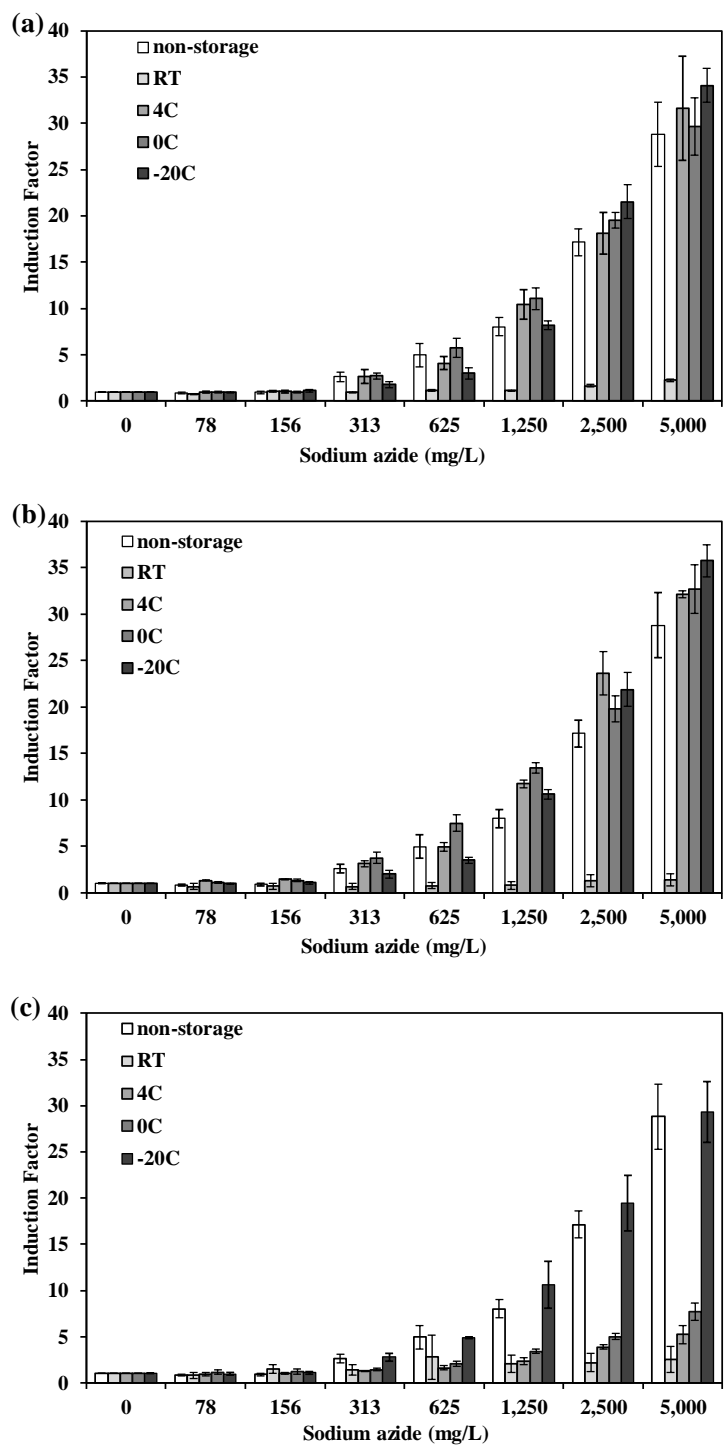

Fig. 3 Genotoxicity induction factor of freeze-dried EREC bioreporter for: (a) 1-month storage, (b) 2-month storage and (c) 3-month storage, when stored at room temperature (RT, $25^{\circ} \mathrm{C}$ ), $4^{\circ} \mathrm{C}, 0^{\circ} \mathrm{C}$ and $-20^{\circ} \mathrm{C}$ compared to a nonstorage freeze-dried cell. Cells were exposed to sodium azide at various concentrations (mg/L); control is nonexposure cell. Data are shown as the mean $\pm \mathrm{SD}$, derived from at least three independent repeats, and the error bars represent the errors of the mean.

tested for the activity of genotoxicity detection by exposing them to sodium azide. During 2-month storage at $4^{\circ} \mathrm{C}$ and $0{ }^{\circ} \mathrm{C}$, the activity remained comparable to that of fresh EREC bioreporter. The 3-month storage and freezing at $-20^{\circ} \mathrm{C}$ showed the highest activity compared to the non-storage 
Table 1 Genotoxicity response of developed EREC bioreporter compared with the standard method: Ames test and commercial SOS-Chromotest $^{\mathrm{TM}}$.

\begin{tabular}{|c|c|c|c|}
\hline & Ames test & SOS-Chromotest ${ }^{\mathrm{TM}}$ & EREC \\
\hline Bacteria & $\begin{array}{l}\text { S. typhimurium } \\
\text { strain TA100 }\end{array}$ & $\begin{array}{l}\text { E. coli PQ37 } \\
\text { (sfi:lacZ) }\end{array}$ & $\begin{array}{l}\text { E. coli DH5 } \alpha \\
\text { (recA:lacZ) }\end{array}$ \\
\hline Assay time & 3-5 days & $3-3.5 \mathrm{~h}$ & $1.5 \mathrm{~h}$ \\
\hline Method & Plate count & Colorimetric & Colorimetric \\
\hline Modified capabilities & $\begin{array}{l}\text { uvrB mutation } \\
\text { rfa mutation }\end{array}$ & $\begin{array}{l}\text { uvrA mutation } \\
\text { tag mutation } \\
\text { rfa mutation }\end{array}$ & \\
\hline \multicolumn{4}{|l|}{ Genotoxicity level } \\
\hline Sodium azide ${ }^{\mathrm{a}}$ & $+(\geqslant 0.78 \mathrm{mg} / \mathrm{L})$ & - & $+(\geqslant 5 \mathrm{mg} / \mathrm{L})$ \\
\hline 4-nitroquinoline 1 -oxide ${ }^{* b}$ & $+(0.15-5 \mathrm{mg} / \mathrm{L})^{\mathrm{c}}$ & $+(\geqslant 0.06 \mathrm{mg} / \mathrm{L})$ & $+(31 \mathrm{mg} / \mathrm{L})$ \\
\hline Benzene* & - & - & $+(1563 \mathrm{mg} / \mathrm{L})$ \\
\hline
\end{tabular}

" carcinogen in humans; ${ }^{\mathrm{a}}$ positive control of Ames test; ${ }^{\mathrm{b}}$ positive control of SOS-Chromotest; ${ }^{\mathrm{c}}$ data from a previous study $[4,40]$. + indicated a positive reaction, and - indicated a negative reaction. uvrAB mutation; deficiency in nucleotide excision repair, tag mutation; inactivation of the constitutive 3-methyl-adenine DNA glycosylase I and rfa mutation; mutation in the core enzymes of lipopolysaccharide (LPS) biosynthesis [29].

cells (Fig. 3). Similar to the previous research, the freeze-dried bioreporter in this study could be kept for months without losing the activity [32]. The initial concentration of fresh bioreporter cell or nonstorage cell and freeze-dried cell were at the same concentration. Storage at low temperature $\left(-20^{\circ} \mathrm{C}\right)$ can maintain cell viability and cell activity. The higher storage temperatures, the faster products will degrade [33]. Accordingly, the storage of freezedried bioreporter at lower temperature $\left(-20^{\circ} \mathrm{C}\right)$ was extending their shelf-life.

\section{The response of freeze-dried EREC bioreporter to pesticides}

At the tested concentrations, carbaryl and carbendazim showed no genotoxic potential while chlorpyrifos, profenofos and cypermethrin were genotoxic at 25, 100 and $100 \mathrm{mg} / \mathrm{L}$, respectively (Fig. S6). Our results indicate that chlorpyrifos, cypermethrin and profenofos were genotoxic on strain EREC and are in agreement with the previous reports $[34,35]$.

MRLs are the maximum residue limits of a pesticide permitted in an agricultural commodity. At the MRL levels or below, there is no adverse health effect on human. Since chili is an important food ingredient and cash crop in Thailand, and various pesticides are widely used in the chili farm [36], the MRL levels of a pesticide residue permitted in Thai agricultural standard of dried pepper chili was used in this study. The MRL levels are as follows: chlorpyrifos $=20 \mathrm{mg} / \mathrm{L}$, carbaryl $=2 \mathrm{mg} / \mathrm{L}$, cypermethrin $=10 \mathrm{mg} / \mathrm{L}$, profenofos $=20 \mathrm{mg} / \mathrm{L}$ and carbendaz-

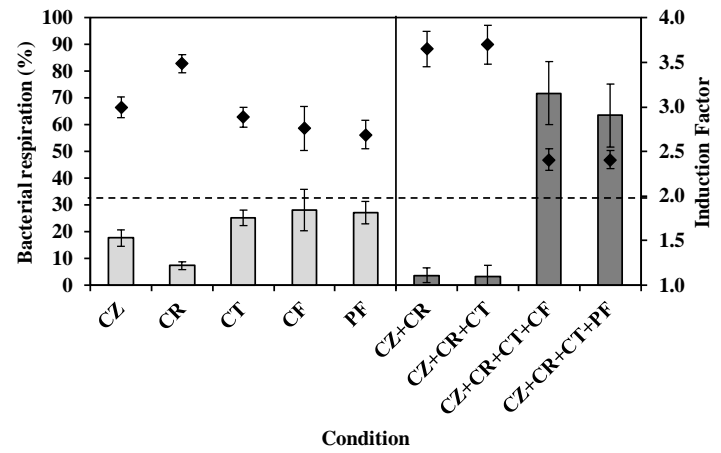

Fig. 4 Bacterial respiration (dot) and genotoxicity induction factor (bar) of the EREC bioreporter when exposed to a mixture of pesticide at MRLs level of pepper chili, dried at $37^{\circ} \mathrm{C}$ for $1 \mathrm{~h}$. The MRL levels of a pesticide residue permitted in agricultural commodity (Thai agricultural standard): chlorpyrifos (CF, MRLs $=20 \mathrm{mg} / \mathrm{L}$ ), carbaryl (CR, MRLs $=2 \mathrm{mg} / \mathrm{L}$ ), cypermethrin (CT, MRLs $=10 \mathrm{mg} / \mathrm{L}$ ), profenofos (PF, MRLsv $=20 \mathrm{mg} / \mathrm{L}$ ) and carbendazim (CZ, MRLs $=20 \mathrm{mg} / \mathrm{L}$ ). The first concentration above the dash line was reported as the minimum genotoxic concentration. Induction factor $>2.0$ indicates genotoxic potential. Data are shown as the mean $\pm S D$, derived from at least three independent repeats, and the error bars represent the errors of the mean.

imn $=20 \mathrm{mg} / \mathrm{L}$. Using EREC bioreporter, exposure to an individual pesticide at the recommended MRLs level does not seem to pose any hazard (Fig. 4). Since pesticides always occur in mixtures with other pesticides, herein the toxicity of pesticide mixtures 
was also tested. Interestingly, the synergistic toxicity was detected from pesticide mixtures of four pesticides including carbendazim + carbaryl + cypermethrin + chlorpyrifos and carbendazim + carbaryl + cypermethrin + profenofos. This result suggested that mixed pesticides should be a concern due to their much higher toxicity, which is in agreement with the other reports on the synergistic effect of the pesticide combination [37,38]. Moreover, the pesticides have been shown to induce oxidative stress by generating reactive oxygen species and genotoxic effects by the irreversible damage to various cell organs [39]. The cumulative toxicological impact of pesticide mixtures is of a particular concern for farmers and people involved in agricultural activities.

\section{CONCLUSION}

The developed colorimetric $E$. coli bioreporter in this study showed effective monitoring of genotoxicity in the model toxicants. The results could correlate well with the standard Ames test and SOS-Chromotest ${ }^{\mathrm{TM}}$; furthermore, the bioreporter can identify benzene as a genotoxic agent. The freeze-dried bioreporter was able to be efficiently used after appropriate storage for three months. Tested with the pesticides, the EREC did not indicate the genotoxicity of individual pesticides at MRL concentrations; however, the positive results were found in the combinations of tested pesticides at MRL levels, suggesting a concern on the synergistic effects of pesticide mixtures. This simple and easy-to-use bioreporter can essentially be applied for monitoring the toxicity of environmental contaminants where the convenient and high-throughput technique is required. For a practical deployment, more validations of the test kit with various chemicals will be essential. The easy and convenient result interpretation with mobile application could be developed. In addition, to further develop this test kit, the sensitivity of the bioreporter host can be improved by cell engineering.

\section{Appendix A. Supplementary data}

Supplementary data associated with this article can be found at http://dx.doi.org/10.2306/ scienceasia1513-1874.2020.039.

Acknowledgements: The authors appreciatively acknowledge Dr. Piya Temviriyanukul (Institute of Nutrition, Mahidol University, Nakhon Pathom, Thailand) for providing S. typhimurium strain TA100. Research grant supported was from the 90th anniversary of Chulalongkorn University Fund. This work was financially supported by the Center of Excellence on Hazardous Substance Management (HSM), Chulalongkorn University and PTT Innovation Institute, Bangkok, Thailand.

\section{REFERENCES}

1. Adjiri A (2017) DNA mutations may not be the cause of cancer. Oncol Ther 5, 85-101.

2. Pang Y, Ren A, Li J, Liang F, Rao R, Gao Y, Wu W, Li D, et al (2020) Development of a sensitive Escherichia coli bioreporter without antibiotic markers for detecting bioavailable copper in water environments. Front Microbiol 10, 1-15.

3. Guadano A, de la Pena E, Gonzalez-Coloma A, Alvarez JF (1999) Development of a new bioluminescent mutagenicity assay based on the Ames test. Mutagenesis 14, 411-415.

4. Maron DM, Ames BN (1983) Revised methods for the Salmonella mutagenicity test. Mutat Res 113, 173-215.

5. Zeiger E (2019) The test that changed the world: The Ames test and the regulation of chemicals. Mutat Res Gen Tox En 841, 43-48.

6. Nunoshiba T, Nishioka H (1991) 'Rec-lac test' for detecting SOS-inducing activity of environmental genotoxic substances. Mutat Res 254, 71-77.

7. Oda Y (2016) Development and progress for three decades in umu test systems. Gene Environ 38, 1-14.

8. Quillardet P, Huisman O, D'Ari R, Hofnung M (1982) SOS chromotest, a direct assay of induction of an SOS function in Escherichia coli K-12 to measure genotoxicity. Proc Natl Acad Sci USA 79, 5971-5975.

9. Legault R, Blaise C, Rokosh D, Chong-Kit R (1994) Comparative assessment of the SOS Chromotest kit and the Mutatox test with the Salmonella plate incorporation (Ames test) and fluctuation tests for screening genotoxic agents. Environ Toxicol Water Qual 9, 45-57.

10. Vollmer AC, Belkin S, Smulski DR, Dyk TK, LaRossa RA (1997) Detection of DNA damage by use of Escherichia coli carrying recA':lux, uvrA'::lux or alkA':lux reporter plasmids. Appl Environ Microb 63, 2566-2571.

11. Ferre DM, Quero AA, Hernandez AF, Hynes V, Tornello MJ, Luders C, Gorla NB (2018) Potential risks of dietary exposure to chlorpyrifos and cypermethrin from their use in fruit/vegetable crops and beef cattle productions. Environ monitg assess 190, 1-10.

12. Xu X, Chen J, Li B, Tang L (2018) Carbendazim residues in vegetables in China between 2014 and 2016 and a chronic carbendazim exposure risk assessment. Food Control 91, 20-25.

13. Ali D, Ali H, Alifiri S, Alkahtani S, Alkahtane AA, Huasain SA (2018) Detection of oxidative stress and DNA damage in freshwater snail textitLymnea leuteola exposed to profenofos. Front Env Sci Eng 12, $1-7$. 
14. Chang X, Xu Y, Liu C (2016) A rapid and sensitive colorimetric measurement of antibiotic efficacy against Escherichia coli in vitro. FEMS Microbiol Lett 363, 1-6.

15. Quillardet P, Hofnung M (1985) The SOS Chromotest, a colorimetric bacterial assay for genotoxins: procedures. Mutat Res 147, 65-78.

16. Nagabhushan M, Amonkar AJ, Bhide SV (1987) In vitro antimutagenicity of curcumin against environmental mutagens. Fd Chem Toxic 25, 545-547.

17. Yang Z, Guan B, Men T, Fujimoto J, Xu X (2013) Comparable molecular alterations in 4-nitroquinoline 1oxide-induced oral and esophageal cancer in mice and in human esophageal cancer, associated with poor prognosis of patients. In Vivo 27, 473-484.

18. Mamber SW, Bryson V, Katz SE (1983) The Escherichia coli WP2/WP100 rec assay for detection of potential chemical carcinogens. Mutat Rese 119, 135-144.

19. Kanojia D, Vaidya MM (2006) 4-Nitroquinoline-1oxide induced experimental oral carcinogenesis. Oral Oncol 42, 655-667.

20. Oda Y, Nakamura S-i, Oki I, Kato T, Shinagawa $\mathrm{H}$ (1985) Evaluation of the new system (umu-test) for the detection of environmental mutagens and carcinogens. Mutat Res 147, 219-229.

21. Anderson D, Yu TW, Schmezer P (1995) An investigation of the DNA-damaging ability of benzene and its metabolites in human lymphocytes, using the comet assay. Environ Mol Mutagen 26, 305-314.

22. Patel M, Jiang Q, Woodgate R, Cox MM, Goodman MF (2010) A new model for SOS-induced mutagenesis: how RecA protein activates DNA polymerase V. Crit Rev Biochem Mol 45, 171-184.

23. Jiang B, Huang WE, Li G (2016) Construction of a bioreporter by heterogeneously expressing a $V i b$ rio natriegens recA::luxCDABE fusion in Escherichia coli, and genotoxicity assessments of petrochemicalcontaminated groundwater in northern China. Environ Sci-Proc Imp 18, 751-759.

24. Allard S (2008) Bioluminescent reporter genes. Postepy Biochem 54, 350-353.

25. AkyÄśl D, Eren Y, Konuk M, Dere H, Serteser A (2017) Genotoxic evaluation of halfenprox using the human peripheral lymphocyte micronucleus assay and the Ames test. Drug Chem Toxicol 40, 191-195.

26. Brennan RJ, Schiestl RH (1998) Free radicals generated in yeast by the Salmonella test-negative carcinogens benzene, urethane, thiourea and auramine O. Mutat Res-Fund Mol M 403, 65-73.

27. DeMarini DM, Lawrence BK, Brooks HG, Houk VS (1991) Compatibility of organic solvents with the Microscreen prophage-induction assay: sol- vent -mutagen interactions. Mutat Res Lett 263, 107-113.

28. Flegrova Z, Skarek M, Bartos T, Cupr P, Holoubek I (2007) Usefulness of three SOS-response tests for genotoxicity detection. Fresen Environ Bull 16, 1369-1376.

29. Biran A, Yagur-Kroll S, Pedahzur R, Buchinger S, Reifferscheid G, Ben-Yoav H, Shacham-Diamand Y, Belkin S (2010) Bacterial genotoxicity bioreporters. Microb Biotechnol 3, 412-427.

30. Pollock Kathryn YG, Moller-Trane R, Koran M, Dosa PI (2016) Combinations of osmolytes, including monosaccharides, disaccharides, and sugar alcohols act in concert during cryopreservation to improve mesenchymal stromal cell survival. Tissue Eng Part C-Me 22, 999-1008.

31. Bock GM, Hyung CS, Woo KS (2001) Some observations in freeze-drying of recombinant bioluminescent Escherichia coli for toxicity monitoring. $J$ Biotechnol 88, 95-105.

32. McLellan MR, Day JG (1995) Overview. In: Day JG, Pennington MW (eds) Cryopreservation and FreezeDrying Protocols, Methods in Molecular Biology 38, Humana Press, Totowa, NJ, pp 1-5.

33. Lobsiger N, Stark WJ (2019) Strategies of immobilizing cells in whole-cell microbial biosensor devices targeted for analytical field applications. Anal Sci 35, 839-847.

34. Okonko L, Ikpeme E, Udensi O (2016) Genotoxic effect of chlorpyrifos and cypermethrin in albino rats. Res J Mutagenesis 6, 31-35.

35. Prabhavathy DG, Pasha SA, Jamil K (2006) Cytotoxicity and genotoxicity induced by the pesticide profenofos on cultured human peripheral blood lymphocytes. Drug Chem Toxicol 29, 313-322.

36. Damalas CA, Eleftherohorinos IG (2011) Pesticide exposure, safety issues, and risk assessment indicators. Int J Env Res Pub He 8, 1402-1419.

37. Cedergreen N (2014) Quantifying synergy: a systematic review of mixture toxicity studies within environmental toxicology. PLoS One 9, 1-12.

38. Zhu YC, Yao J, Adamczyk J, Luttrell R (2017) Synergistic toxicity and physiological impact of imidacloprid alone and binary mixtures with seven representative pesticides on honey bee (Apis mellifera). PLoS One 12, 1-16.

39. Brar SK, Khera KS (2019) Profenofos induced oxidation stress and genotoxicity in female albino rats. Pestic Res $J$ 31, 172-178.

40. McCoy EC, Petrullo LA, Rosenkranz HS, Mermelstein R (1981) 4-Nitroquinoline-1-oxide: factors determining its mutagenicity in bacteria. Mutat Res 89, 151-159. 


\section{Appendix A. Supplementary data}

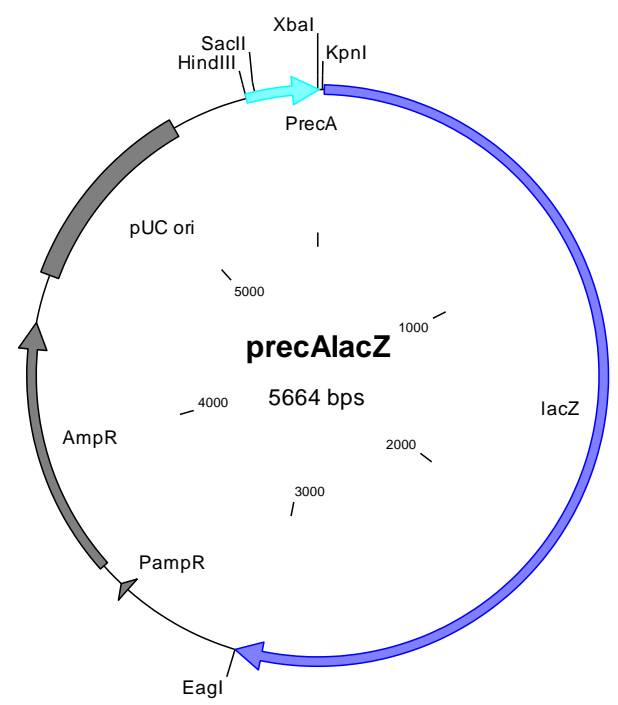

Fig. S1 Schematic organization of plasmid in the E. coli EREC: $\mathrm{P}_{\text {rec }}$ lacZ was constructed by fusing promoter recA into the HindIII and XbaI sites of a promoterless pUC19 containing lacZ gene and Amp ${ }^{r}$ (ampicillin resistance).

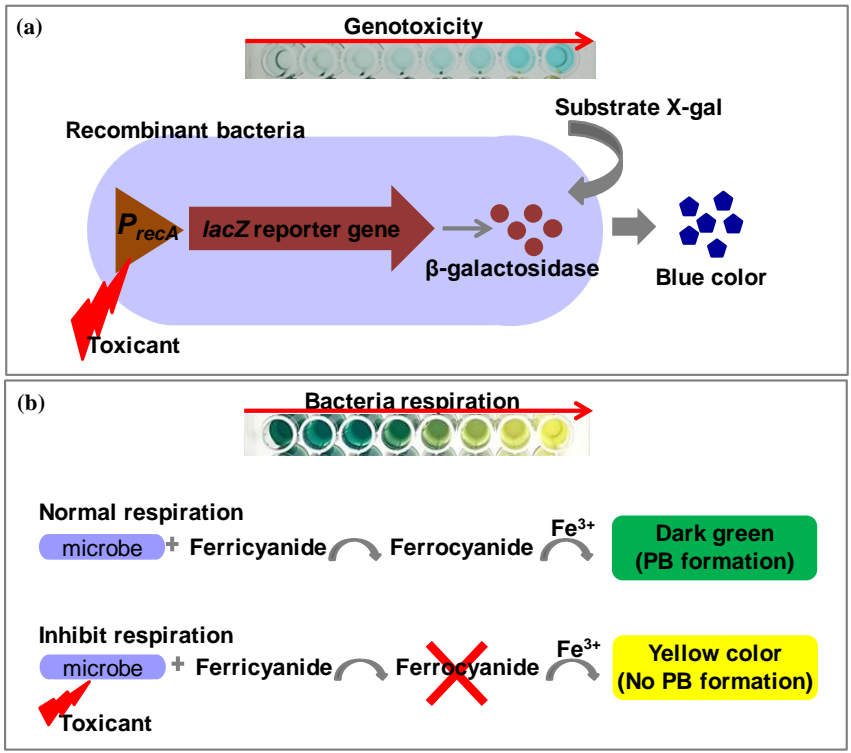

Fig. S2 Principle of colorimetric bacterial bioreporter (a) lacZ-based recombinant bacteria for genotoxicity detection. When cell exposed to toxicant shows the related effect to DNA damage, the promoter activated the downstream reporter gene coding protein, and after substrate addition, the signal occurred corresponding to the stress level. (b) Bacterial respiration using prussian blue (PB) as a colorimetric indicator. Ferricyanide is easily reduced by bacterial metabolism to ferrocyanide, and ferrocyanide reacts with ferric ion to form prussian blue or green color pigment. In the presence of a toxic agent, the bacterial metabolic activity is reduced or stopped, with a consequent decrease in the ferrocyanide reduction rate to prussian blue formation. 
(a)

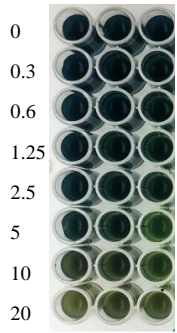

(b)

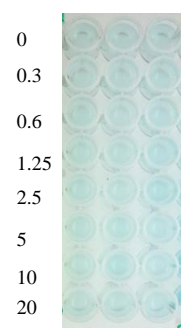

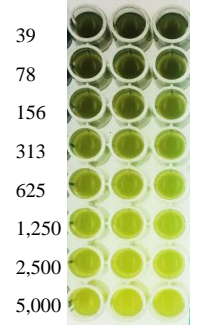

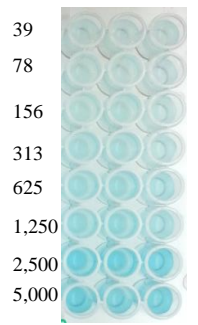

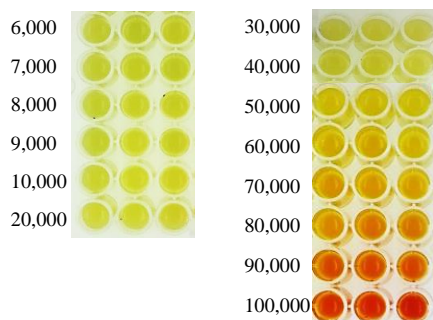
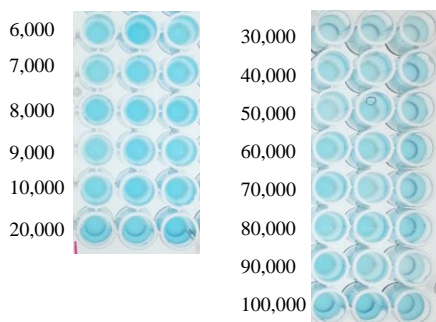

(c)

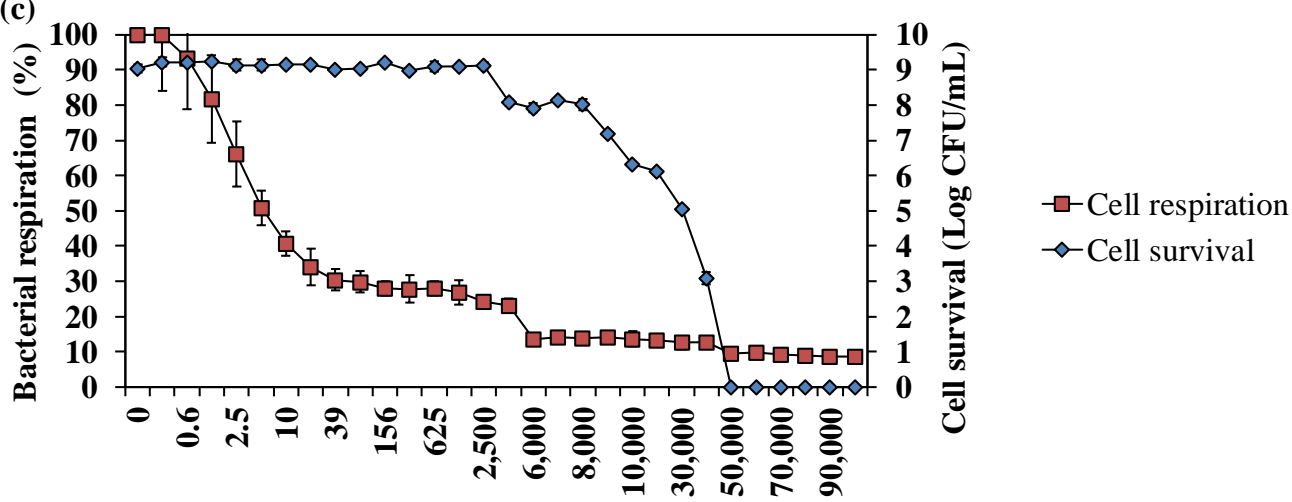

Sodium azide (mg/L)

Fig. S3 (a) Color expression of bacterial respiration; (b) color expression of $\beta$-galactosidase production; and (c) comparison survivability based on cell respiration and colony forming unit. The cut off of cell alive and cell death was orange color or $<20 \%$ bacterial respiration. Cells were exposed to sodium azide at various concentration (mg/L) at $37^{\circ} \mathrm{C}$ for $1 \mathrm{~h}$. The data are the mean with standard deviation from at least three replicates.

(a)

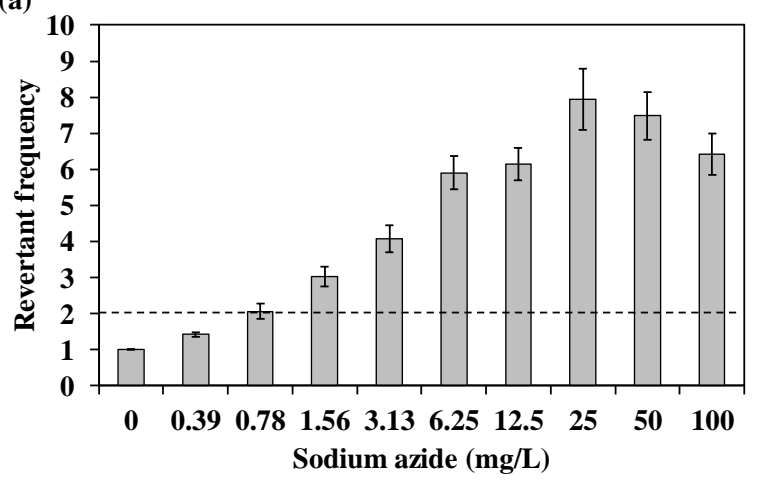

(b)

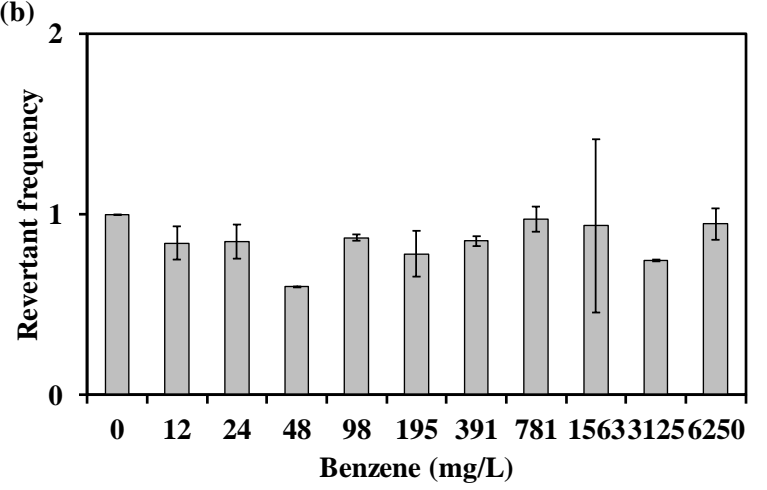

Fig. S4 Mutagenic result by the Ames test of $S$. typhimurium strain TA100 exposed to (a) sodium azide and (b) benzene. The first concentration above the dash line was reported as the minimum genotoxic concentration. Data are shown as the mean $\pm S D$, derived from at least three independent repeats, and the error bars represent the errors of the mean. 
(a)

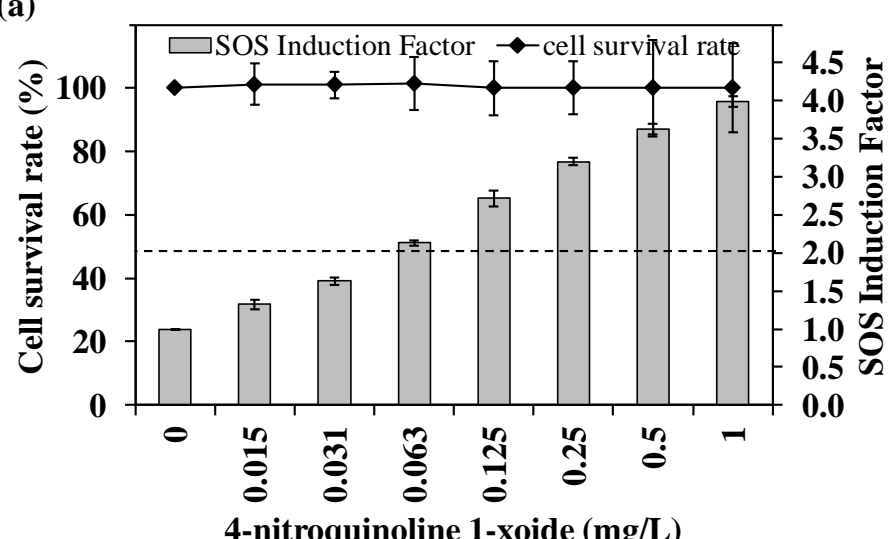

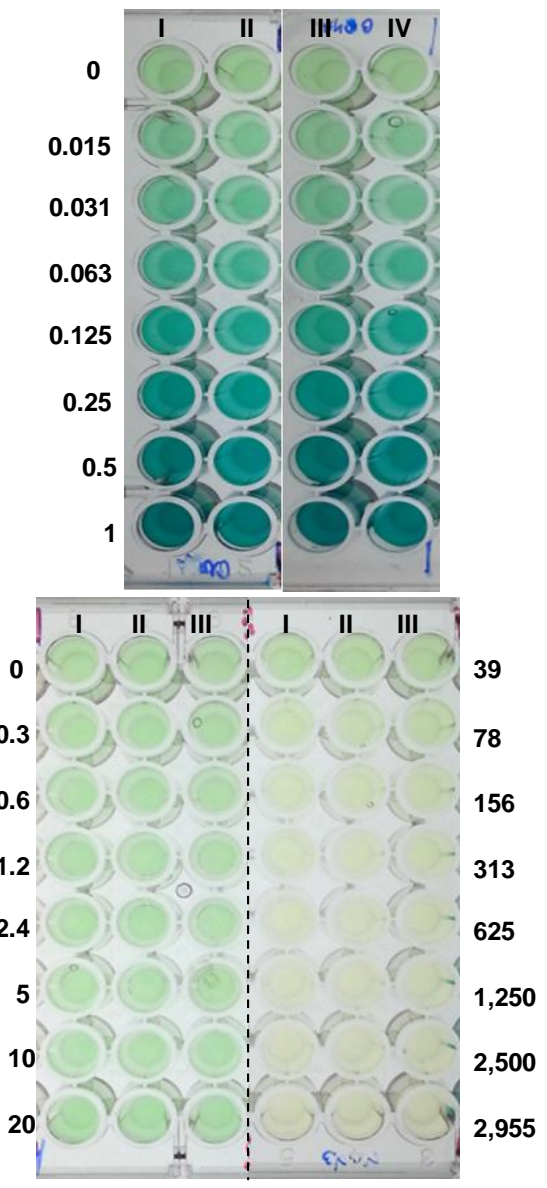

(b)

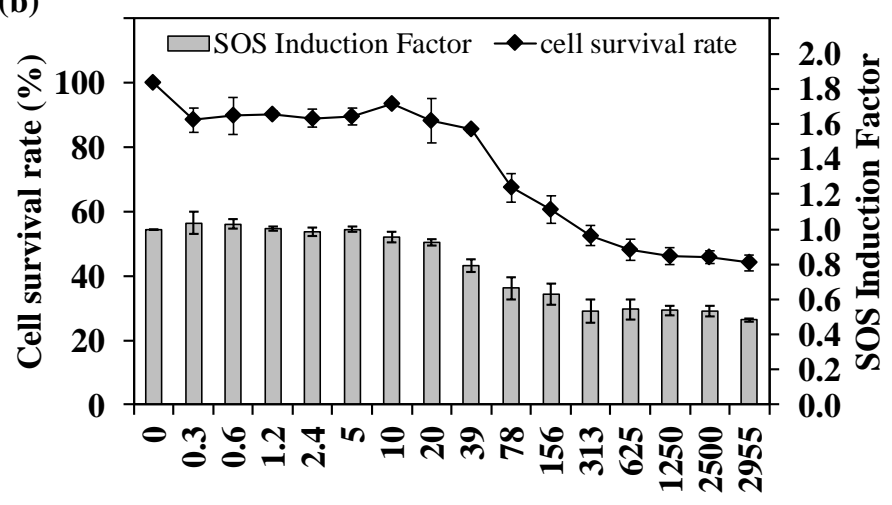

Sodium azide $(\mathrm{mg} / \mathrm{L})$

(c)

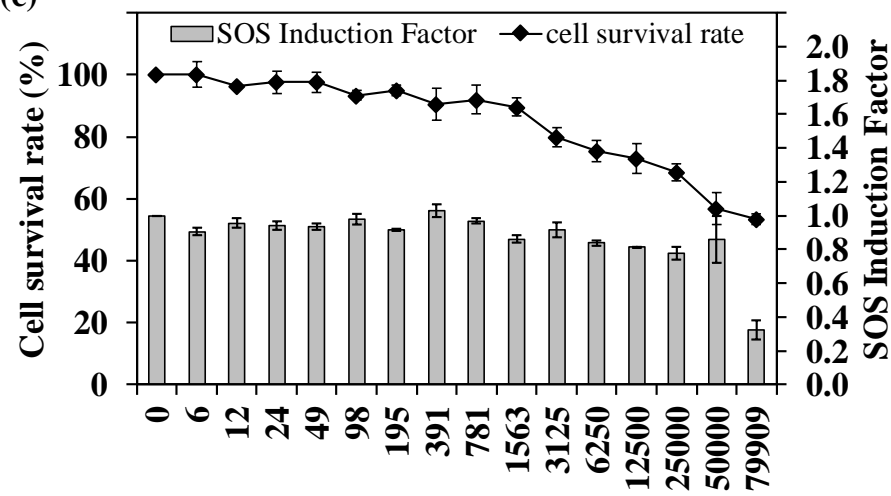

Benzene (mg/L)

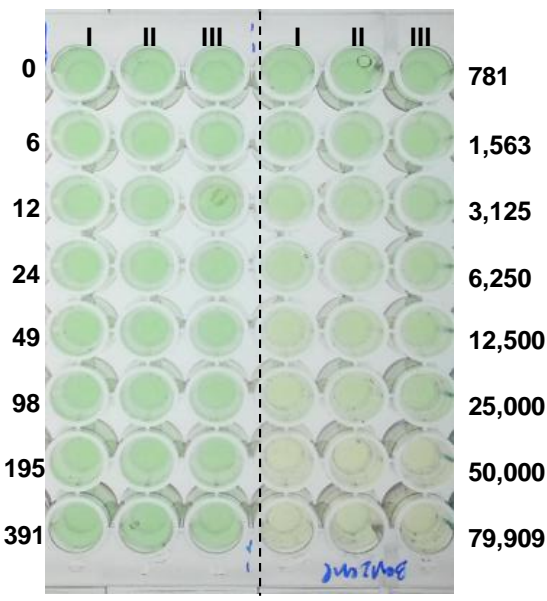

Fig. S5 Cell survival rate (line) and SOS induction factor (bar) of SOS-Chromotest using E. coli PQ37 (sfi:lacZ) exposed to (a) 4-nitroquinoline 1-oxide, (b) sodium azide and (c) benzene. Control is non-exposure cell. A survival rate of $80 \%$ is required to confirm a positive result, and SOS induction factor $>2.0$ is classified as genotoxic. The first concentration above the dash line was reported as the minimum genotoxic concentration. Data are shown as the mean $\pm \mathrm{SD}$, derived from at least three independent repeats, and the error bars represent the errors of the mean. 
(a)

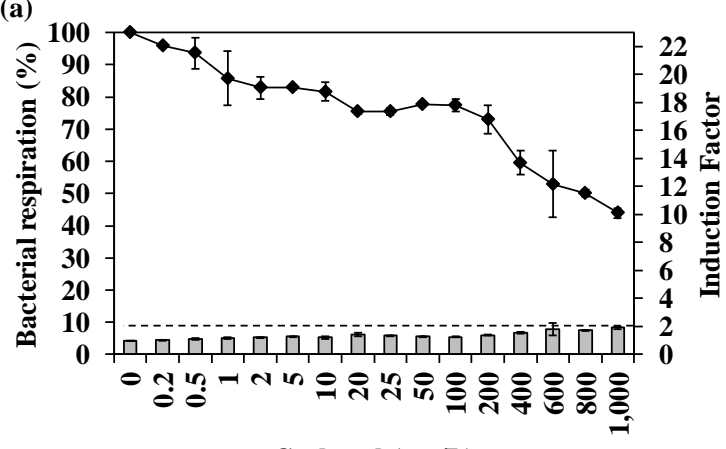

(c)

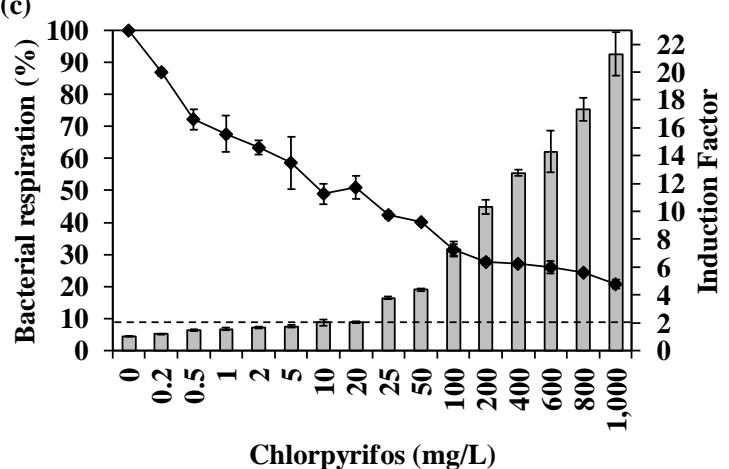

(e)

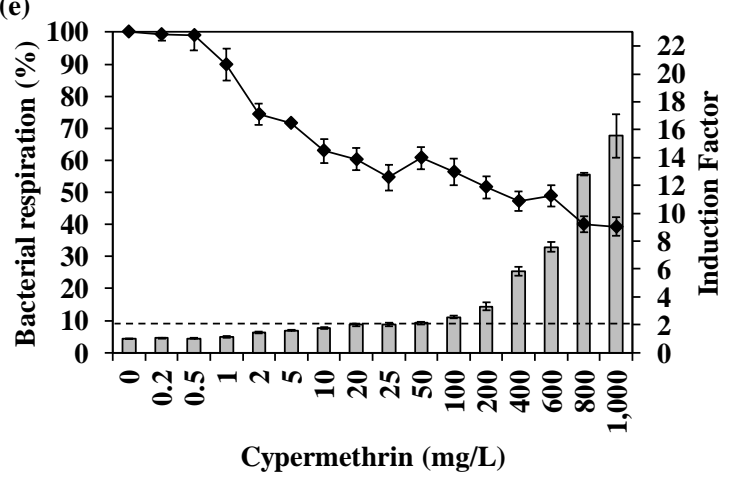

(b)

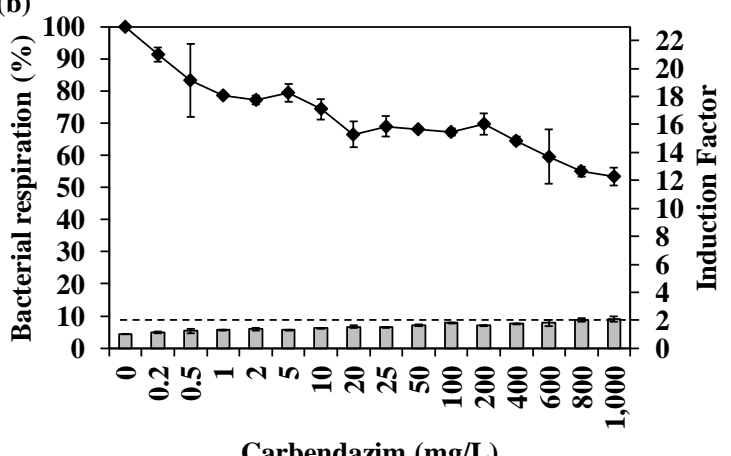

(d)

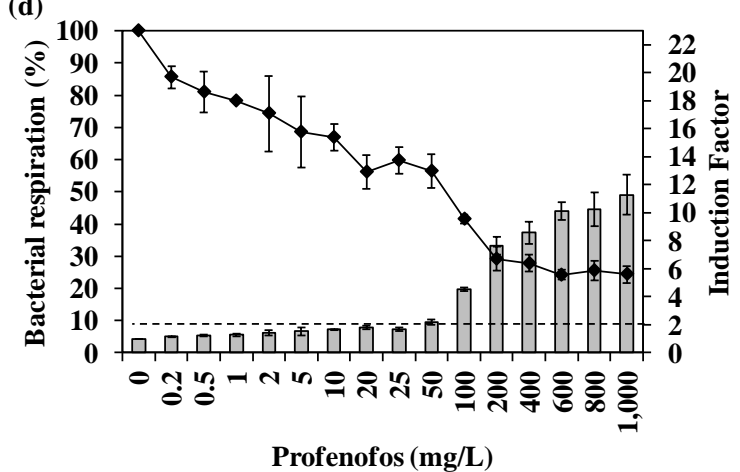

Fig. S6 Bacterial respiration (line) and genotoxicity induction factor (bar) of the E. coli EREC when exposed to the pesticide at $37^{\circ} \mathrm{C}$ for $1 \mathrm{~h}$; (a) carbaryl, (b) carbendazim, (c) chlorpyrifos, (d) profenofos and (e) cypermethrin. The first concentration above the dash line was reported as the minimum genotoxic concentration. Induction factor $>2.0$ indicates genotoxic potential. Data are shown as the mean $\pm \mathrm{SD}$, derived from at least three independent repeats, and the error bars represent the errors of the mean. 